DOI: $10.17957 / \mathrm{IJAB} / 15.1834$

http://www.fspublishers.org

Full Length Article

\title{
Productivity of Phosphorus Fertilization in Cowpea-Maize Strip Intercropping under Rainfed Conditions
}

\author{
Joseph Nwafor Akanwe Asiwe ${ }^{\mathbf{1}^{*}}$, Mzamani Knowledge Nkuna ${ }^{1}$ and Peter P. Motavalli ${ }^{2}$ \\ ${ }^{1}$ Department of Plant Production, Soil Science and Agricultural Engineering, School of Agricultural and Environmental \\ Science, University of Limpopo, RSA, P/Bag X1106, Sovenga 0727 \\ ${ }^{2}$ School of Natural Resources, University of Missouri, 302 Anheuser-Busch Natural Resources Building, Columbia, MO \\ 65211, USA \\ *For correspondence: joseph.asiwe@ul.ac.za \\ Received 01 February 2021; Accepted 04 May 2021; Published 10 July 2021
}

\begin{abstract}
Crop yields are declined due to low soil fertility, insufficient soil water availability and poorly managed cropping systems in Limpopo province of South Africa. Phosphorus (P) is a major essential nutrient element required by crops for enhanced growth and development. Interactions between different rates of $\mathrm{P}$ fertilization and strip intercropping system have not been studied in detail under rainfed conditions in semi-arid region of Limpopo province. Therefore, this study was conducted to assess the performance of four cowpea varieties at four levels $\left(0,15,30,45 \mathrm{~kg} \mathrm{P} \mathrm{ha}^{-1}\right)$ of $\mathrm{P}$ fertilization in a cowpea-maize intercropping system in a split-split plot design during two seasons. Significant interactions were obtained between variety and phosphorus application as well as variety and cropping system for $90 \%$ physiological maturity, root mass and grain yield in both seasons. P levels significantly influenced and enhanced grain yield, land equivalent ratio, profit and benefit cost ratio achieved. PAN311 and TVu13464 matured earlier across P levels and they were selected promising cowpea varieties based on their early maturity and high yield. Land equivalent ratio values were greater than 1.0, which indicated performance and advantage of an intercropping system over monocropping system in land utilisation. The optimum P level for cowpea-maize strip intercropping was at $30 \mathrm{~kg} \mathrm{P} \mathrm{ha}^{-1}$ based on yield and financial return. The results showed that $\mathrm{P}$ application enhanced the productivity of the cowpea varieties in cowpea-maize strip intercropping in the semi-arid environment of Limpopo province. (C) 2021 Friends Science Publishers
\end{abstract}

Keywords: Benefit cost ratio; Cropping system; Grain yield; Land equivalent ratio; Vigna unguiculata

\section{Introduction}

In Southern Africa, the intensity and frequency of floods and drought due to climate change have increased resulting in the shift of rainfall onset, and has led to erratic, unpredictable and uneven distributed rainfall (Sikora et al. 2020). Farmers are struggling to cope with the persistent effects of climate change. Limpopo province is a semi-arid region prone to drought (Mpandeli et al. 2015), characterised by sandy soils with inadequate native nutrient elements, particularly nitrogen and phosphorus (Odhiambo and Nemadodzi 2007). Adeyemi et al. (2020) described cowpea (Vigna unguiculata) as an important legume crop in less developed countries because it is nutritionally rich in proteins and minerals (Kermah et al. 2017; Mafakheri et al. 2017), used for both human consumption and livestock feeding. Although it is mainly grown as grain legume crop (Asiwe et al. 2020); its young leaves and immature pods are used as a vegetable (Kyei-Boahen et al. 2017). Inclusion of cowpea in cropping systems has the potential to increase crop yield due to residual fixed nitrogen (Namatsheve et al. 2020; Asiwe and Maimela 2021) and improves soil fertility of smallholder farming systems where little or no synthetic fertiliser is used (Kyei-Boahen et al. 2017).

Most smallholder farmers in the Limpopo province Practice mixed cropping system where crops are not planted in definite rows. This traditional practice compromises crop yields in many ways due to the fact that it does not optimise plant population, and secondly, it does not permit mechanisation and application of farm inputs (Asiwe 2009). According to Maitra et al. (2020), strip intercropping (growing two or more component crops together in wider strips to facilitate individual crop production, but close enough to improve crop interaction) can increase crop yield beyond monoculture system or other forms of intercropping system because managing the individual crop within the strip is easy and the competition between the component crops is reduced (Gebregergis 2016).

Phosphorus (P) is one of the important essential nutrient elements for crop production (Nkaa et al. 2014;

To cite this paper: Asiwe JNA, MK Nkuna, PP Motavalli (2021). Productivity of phosphorus fertilization in cowpea-maize strip intercropping under rainfed conditions. Intl J Agric Biol 26:270-276 
Nongqwenga and Modi 2017) due to its significant role in numerous plant processes including photosynthesis, respiration, cell division and energy transformation (Karikari et al. 2015). The work of Adeyemi et al. (2020) and Namakka et al. (2017) revealed that P plays an important role in the growth, seed development, nitrogen fixation of cowpea and overall yield of the crop. Despite the critical role of $\mathrm{P}$ in crops, it remains one of the least available plant nutrient elements (Nziguheba et al. 2016) due to its relative immobility and sorption in soils (Mndzebele et al. 2020). Many studies have reported that $\mathrm{P}$ improves early root formation and development, and therefore enhances drought tolerance of crops (Sudharani et al. 2020). Various studies on $\mathrm{P}$ application under intercropping have been conducted (Nndwambi et al. 2016; Mndzebele et al. 2020); however, the application of $\mathrm{P}$ under a cowpea-maize (Zea mays L.) strip intercropping situation has not been studied in detail in the semi-arid Limpopo region. Therefore, the objective of this study was to assess the effect of $\mathrm{P}$ fertilization on four cowpea varieties planted in a strip intercropping with maize. The hypothesis was to find out whether $\mathrm{P}$ application would influence the yield components and productivity of the cowpea varieties sown as cowpea-maize strip intercropping systems under rainfed conditions.

\section{Materials and Methods}

\section{Description of the study area}

The experiment was conducted at the University of Limpopo experimental farm (Syferkuil) located in Mankweng, Capricorn District, Limpopo province, South Africa (235' 9.6" $\mathrm{S}$ and $\left.29^{\circ} 43^{\prime} 4.8^{\prime \prime} \mathrm{E}\right)$. The study area is characterised by sandy loam texture belonging to Hutton form, low erratic summer rainfall ranging from 400 to $650 \mathrm{~mm}$ (Table 2).

\section{Experimental materials}

The trial was planted in a split-split plot design during the $2014 / 2015$ and 2015/2016 planting seasons. A maize variety (WE3127) and four cowpea varieties (PAN311, IT86D1010, TVu13464 and IT82D-889) were used in a strip intercropping in 2014/15 growing season. Two promising cowpea varieties (PAN311 and TVu13464) were selected and used in the second season trial based on their early maturity and high yielding. The main-plot factor was a single superphosphate $(8.1 \% \mathrm{P})$ fertiliser at four different levels of $0,15,30$ and $45 \mathrm{~kg} \mathrm{P} \mathrm{ha}^{-1}$ applied during planting through band placement at a depth of $50 \mathrm{~mm}$ below the seed. Subplot factor consisted of four levels of cowpea varieties arranged in cropping systems (monocropping and intercropping) which formed the sub-sub plot. Each plot was $2 \mathrm{~m} \times 3 \mathrm{~m}$ with an alley way of $1 \mathrm{~m}$. Maize was spaced at $90 \mathrm{~cm} \times 30 \mathrm{~cm}$, while cowpea was spaced at $75 \mathrm{~cm} \times 20$ $\mathrm{cm}$. Four rows of cowpea sandwich between four rows of maize. The trial was replicated three times.

\section{Crop management}

The experimental plot was prepared with tractor-mounted implements (disc plough and harrow) to enhance the seed bed for good germination and seedling emergence. The first season trial was planted on 11 February 2015 and on 19 February 2016 for the second season. Herbicide application rates described by Asiwe and Maimela (2021) for Round-up with active ingredient of Glyphosate, N-(phosphonomethyl) glycine, in the form of its isopropylamine salt $(240 \mathrm{~mL} / 15 \mathrm{~L}$ water knapsack $=3 \mathrm{~L} \mathrm{ha}^{-1}$ ) and Dual gold with active ingredient of $\mathrm{S}$-metolachlor (chloro-acetanilide) $(30 \mathrm{~mL} / 15$ $\mathrm{L}$ water knapsack $=0.5 \mathrm{~L} \mathrm{ha}^{-1}$ ) were applied to control weeds before planting. Manual weeding was done subsequently on growing weeds in the field. Several sprays (3-4) of insecticide were applied on cowpea plants as reported by Asiwe and Maimela (2021). Karate 2.5 EC with active ingredient of lambda-cyhalothrin (pyrethroid) (60 $\mathrm{mL} / 15 \mathrm{~L}$ water knapsack $=1 \mathrm{~L} \mathrm{ha}^{-1}$ ) was used to control insect pests (blister beetles and pod-sucking bugs) on cowpea from seedling stage until pod maturity while an Aphox with active ingredient of pirimicarb (carbamate) (4 $\mathrm{g} / 15 \mathrm{~L}$ water knapsack $=500 \mathrm{~g} \mathrm{ha}^{-1}$ ) was used to control cowpea aphids.

\section{Soil analysis}

Initial soil samples were collected at a depth of $0-15 \mathrm{~cm}$ using a soil auger before treatments were applied. The soil cores were thoroughly mixed, and a $1 \mathrm{~kg}$ composite sample was then air dried and sieved with a $2 \mathrm{~mm}$ mesh sieve. Laboratory analyses were conducted on the soil samples using different recommended laboratory methods to determine $\mathrm{pH}, \mathrm{N}, \mathrm{P}$ and $\mathrm{K}$. Soil $\mathrm{pH}\left(\mathrm{H}_{2} \mathrm{O}\right)$ was determined using 1:2.5 soil-water ratio as described by Eckert (1988), whereas plant available $\mathrm{P}$ was determined using the Bray-P1 extractant as described by Kuo (1996). The total N was determined by macro-Kjeldahl digestion method as described by Bremner (1955) while $\mathrm{K}$ was extracted using ammonium acetate $(1 \mathrm{~N})$ as described by Chapman (1965). Soil analysis results are presented in Table 1 . Given the critical levels of the nutrients NPK as 10,20 and $75 \mathrm{mg} \mathrm{kg}^{-1}$ Fulton (2010) respectively, it suggests that the soil nutrient content of these major elements was slightly or marginally above the critical levels and therefore offers the plants the opportunity to respond to $\mathrm{P}$ application.

\section{Data collection}

Data on days to flowering were recorded by counting the days from the date of emergence to the date when $50 \%$ of the plant population had flowered. Physiological maturity was calculated by counting the days from the date of emergence to when $90 \%$ of the plant population had attained physiological maturity in each subplot. At podding stage, five plants from the middle rows were randomly 
Table 1: Initial selected physical and chemical properties of the experimental field site during first and second growing seasons

\begin{tabular}{lll}
\hline Soil properties & Season 1 & Season 2 \\
\hline Physical properties & & \\
Silt $(\%)$ & 26.39 & 20.73 \\
Clay $(\%)$ & 3.85 & 8.35 \\
Sand $(\%)$ & 69.76 & 60.92 \\
Texture class & Sandy loam & Sandy loam \\
Chemical properties & & \\
pH $\left(\mathrm{H}_{2} \mathrm{O}\right)$ & 6.71 & 6.53 \\
Available P $\left(\right.$ Bray1) $\left(\mathrm{mg} \mathrm{kg}^{-1}\right)$ & 25.70 & 23.28 \\
Total N (mg kg & \\
K (mg kg & 15.2 & 18.4 \\
\hline $\mathrm{P}=$ Phosphorus; $\mathrm{N}=$ Nitrogen; $\mathrm{K}=$ Potassium & & 92.5 \\
\hline
\end{tabular}

Table 2: The average monthly rainfall, minimum (Tn) and maximum (Tx) temperature during the two growing seasons at Syferkuil experimental farm

\begin{tabular}{lllllll}
\hline Month & \multicolumn{3}{c}{ Season 1 } & \multicolumn{3}{c}{ Season 2 } \\
\cline { 2 - 7 } & $\mathrm{Tx}\left({ }^{\circ} \mathrm{C}\right)$ & $\mathrm{Tn}\left({ }^{\circ} \mathrm{C}\right)$ & Rainfall $(\mathrm{mm})$ & $\mathrm{Tx}\left({ }^{\circ} \mathrm{C}\right)$ & $\mathrm{Tn}\left({ }^{\circ} \mathrm{C}\right)$ & Rainfall $(\mathrm{mm})$ \\
\hline Jan & 28.37 & 15.65 & 43.68 & 25.57 & 17.30 & 87.36 \\
Feb & 29.88 & 15.56 & 24.13 & 29.12 & 17.54 & 57.13 \\
Mar & 28.32 & 14.62 & 14.47 & 28.14 & 15.83 & 126.73 \\
Apr & 25.27 & 11.24 & 81.28 & 26.84 & 11.65 & 0.18 \\
May & 26.27 & 5.91 & 0.25 & 21.69 & 7.28 & 0.00 \\
Jun & 21.75 & 2.75 & 4.57 & 21.40 & 3.87 & 0.00 \\
\multicolumn{3}{l}{ Source: University of Limpopo Experimental Farm Weather Station }
\end{tabular}

selected and carefully dug out by using a digging fork and cut at the soil surface level with minimal damage to the roots. The fresh roots from five randomly selected plants were separately shaken off the clogging soil particles and weighed using a weighing scale, and the average weight was obtained to represent root weight per plant.

\section{Plant harvesting}

At physiological maturity, cowpea pods were harvested in late May of each year. Two middle rows of cowpea were manually harvested (excluding plants that were designated for sampling) as net plot and pods were threshed manually. After threshing, the seeds were weighed using a weighing scale to determine net shelled seed weight. Two middle rows of maize were manually harvested in July when the cobs are dry and the cobs were threshed manually to obtain the net shelled maize grain weight. The grain weight of cowpea and maize per net plot were calculated and extrapolated as yield in $\mathrm{kg} \mathrm{ha}^{-1}$ using the following formula:

$$
\begin{aligned}
\text { Grain yield }\left(\mathrm{kg} \mathrm{ha}^{-1}\right) & =(\text { Grain weight }[\mathrm{kg}]) /(\text { area harvested } \\
& {\left.\left[\mathrm{m}^{2}\right]\right) \times 10000 \mathrm{~m}^{2} }
\end{aligned}
$$

\section{Land equivalent ratio (LER)}

The productivity of the intercropping system was determined by computing LER. The total LER was calculated from the relative yield of cowpea and maize with their monocropping variables as described by Dariush et al. (2006) using the formula:

$$
\text { Total LER }=\sum(\text { Ypi/Ymi })
$$

Where Yp represents the yield of individual crops in the intercropping system and $\mathrm{Ym}$ is the yield of the crop in the monoculture system. An advantageous intercropping system was attained when LER was greater than 1.00, which indicates greater efficiency of land utilisation in an intercropping system (Asiwe and Maimela 2021). The LER for the crop mixtures for each year was calculated and the combined average was computed for the crop mixtures.

\section{Economic analysis}

A benefit-cost analysis was conducted as described by Asiwe and Maimela (2021) to estimate the economic achievements of the different crop mixtures in the intercropping systems as influenced by $\mathrm{P}$ application rates. The production costs of cowpea and maize included the cost of field preparation, seed, sowing, fertiliser, crop protection measures, harvesting, and processing. The total cost and revenue were estimated using the prevailing average market prices in Rand for the grain yield of cowpea ( $\left.\mathrm{R} 40.00 \mathrm{~kg}^{-1}\right)$ and maize $\left(\mathrm{R}^{2} .00 \mathrm{~kg}^{-1}\right)$ in South Africa. The amount in Rand was converted to USD by dividing with the average exchange rate of $14.01 \mathrm{ZAR} / \$$. The total profit was calculated by subtracting the total cost from the total revenue, while the benefit-cost ratio (BCR) was calculated by dividing the total profit by the total cost.

\section{Statistical Analysis}

The data generated on growth and yield parameters were subjected to analysis of variance (ANOVA) procedure using a three-way ANOVA to determine variation among the factors and treatment means using GENSTAT 20.1 version. Fisher's Protected Least Significance Difference (LSD) was used to separate the means that showed significant differences at $P \leq 0.05$.

\section{Results}

The results showed that interactions were not significant in some of the variables recorded for the factors. However, the main effects ( $P$ application level, variety and cropping system) as well as interactions had non-significant effect $(P$ $\geq 0.05$ ) on the number of days to $50 \%$ flowering during both seasons. However, the varieties significantly $(P \leq 0.05)$ differed in the number of days to attain $90 \%$ physiological maturity (Table 3 ) during both seasons but for the cropping system, significant difference was only observed during the second season. The interactions between variety and cropping system showed significant difference during both seasons. Cropping system significantly influenced the varieties in the number of days to attain $90 \%$ physiological maturity during the second season, and the intercropping matured earlier than the monocropping. Mean number of days to maturity was also observed to be consistently longer during the second season than the first season. There was a 
Table 3: Effect of phosphorus application and cropping system and its interactive effect on number of days to $50 \%$ flowering, $90 \%$ physiological maturity and plant height of cowpea varieties

\begin{tabular}{|c|c|c|c|c|c|c|}
\hline \multirow[t]{2}{*}{ Treatment } & \multicolumn{3}{|c|}{ Season 1} & \multicolumn{2}{|c|}{ Season 2} & \multirow[b]{2}{*}{$\begin{array}{l}\text { Plant height } \\
(\mathrm{cm})\end{array}$} \\
\hline & $\begin{array}{l}\text { Days to } 50 \% \\
\text { flowering (days) }\end{array}$ & Days to $90 \%$ maturity (days) & Plant height $(\mathrm{cm})$ & $\begin{array}{l}\text { Days to 50\% flowering } \\
\text { (days) }\end{array}$ & $\begin{array}{l}\text { Days to } 90 \% \text { maturity } \\
\text { (days) }\end{array}$ & \\
\hline \multicolumn{7}{|c|}{ Phosphorus $\left(\mathrm{P} ; \mathrm{kg} \mathrm{ha}^{-1}\right)$} \\
\hline 0 & $56.17^{\mathrm{NS}}$ & $99.17^{\mathrm{NS}}$ & $49.44^{\mathrm{NS}}$ & $60.61^{\mathrm{NS}}$ & $102.44^{\mathrm{NS}}$ & $50.12 \mathrm{a}$ \\
\hline 15 & 56.42 & 101.87 & 48.75 & 60.78 & 101.61 & $51.70 \mathrm{a}$ \\
\hline 30 & 55.92 & 99.63 & 49.58 & 60.22 & 101.67 & $54.33 \mathrm{~b}$ \\
\hline 45 & 56.25 & 99.83 & 50.83 & 59.83 & 103.11 & $55.19 \mathrm{~b}$ \\
\hline \multicolumn{7}{|l|}{ Varieties (V) } \\
\hline IT82D-889 & $58.00^{\mathrm{NS}}$ & $95.32 \mathrm{a}$ & $58.33 \mathrm{a}$ & & & \\
\hline PAN311 & 53.67 & $93.46 \mathrm{a}$ & $50.00 \mathrm{~b}$ & $59.58 \mathrm{a}$ & $97.12 \mathrm{a}$ & $65.41 \mathrm{a}$ \\
\hline IT86D-1010 & 58.83 & $104.87 \mathrm{~b}$ & $52.50 \mathrm{~b}$ & & & \\
\hline TVu13464 & 54.25 & $101.67 \mathrm{~b}$ & $36.88 \mathrm{c}$ & $60.83 \mathrm{a}$ & $109.46 \mathrm{~b}$ & $40.06 \mathrm{~b}$ \\
\hline \multicolumn{7}{|c|}{ Cropping system (CS) } \\
\hline Monocrop & $56.47^{\mathrm{NS}}$ & $98.60^{\mathrm{NS}}$ & $49.90^{\mathrm{NS}}$ & $60.39^{\mathrm{NS}}$ & $103.65 \mathrm{a}$ & $53.46^{\mathrm{NS}}$ \\
\hline Intercrop & 56.19 & 99.06 & 49.17 & 60.31 & $99.32 b$ & 52.29 \\
\hline \multicolumn{7}{|l|}{ Interactions } \\
\hline $\mathrm{V} \times \mathrm{P}$ & 0.59 & 0.82 & 0.96 & 0.84 & 0.07 & 0.94 \\
\hline $\mathrm{V} \times \mathrm{CS}$ & 0.15 & 0.01 & 0.32 & 0.20 & 0.01 & 0.04 \\
\hline $\mathrm{V} \times \mathrm{P} \times \mathrm{CS}$ & 0.83 & 0.89 & 0.80 & 0.32 & 0.15 & 0.97 \\
\hline
\end{tabular}

significant $(P \leq 0.05)$ interaction between the cropping system and variety for plant height during the second season (Table 3). With regards to the main effects, significant differences were observed among the varieties during both seasons while among the among the $\mathrm{P}$ levels it was observed only during the first season.

Phosphorus application significantly $(P \leq 0.05)$ influenced root mass production (Table 4 ), where $\mathrm{P}$ application at 30 and $45 \mathrm{~kg} \mathrm{P}^{-1}$ achieved the highest root mass during both seasons. The interactive effect between variety and phosphorus application was significant for both seasons while between the variety and cropping system, significant interaction was obtained only during the second season. The intercropping exhibited higher root mass than the monocropping during both seasons. The 100-seed weight differed significantly $(P \leq 0.05)$ only among the varieties during both seasons (Table 4 ). For the grain yield, there were significant difference $(P \leq 0.05)$ for the main effects and interactions (Table 4). Increasing $\mathrm{P}$ application increased mean grain yield during both seasons. PAN311 and TVu13464 achieved higher yield during the two seasons. Intercropping exhibited significant effect over monocropping during both seasons. The results also showed significant difference in the interaction between the variety and cropping system during both seasons and between variety and phosphorus application during first season only.

Table 5 shows that $\mathrm{P}$ application significantly $(P \leq$ 0.05 ) influenced the LER among the cowpea varieties intercropped with maize. LER values ranged from 1.90 to 2.87 during the first season and from 1.0 to 1.80 in the second season. The LER values for PAN311 and IT82D889 increased from $0-30 \mathrm{~kg} \mathrm{P} \mathrm{ha}^{-1}$ during both seasons but beyond that point it decreased while the LER values of IT86D-1010 increased with the increasing P levels. The results also showed that the LER mean values declined at 45 $\mathrm{kg} \mathrm{P} \mathrm{ha}{ }^{-1}$ during both seasons.
The summary of the effect of $\mathrm{P}$ application on the monetary values obtained from grain yield of cowpea-maize crop mixtures are shown in Table 6 . The profit obtained was in direct relationship with the amount of $\mathrm{P}$ applied. However, the value of BCR peaked at $30 \mathrm{~kg} \mathrm{P} \mathrm{ha}^{-1}$ and declined at $45 \mathrm{~kg}$ $\mathrm{P} \mathrm{ha}^{-1}$. The Profit and BCR achieved by the intercropping were higher than that achieved by monocropping.

\section{Discussion}

This study has demonstrated that $\mathrm{P}$ application influenced the achievement of the varieties and the cropping systems with respect to the grain yield, profit and other yield components studied, and earns great potential in improving the productivity of farmers in Limpopo Province. Although, the significant interaction between variety and cropping system may indicate that cropping system influenced the maturity of the varieties but this trend was not obtained as the intercrop was not significantly different from monocropping but may have exerted its influence on the varieties where differences were observed. In the light of this, two varieties (PAN311 and TVu13464) matured earlier and were more adapted to micro-environment created by the intercropping system than the other two varieties (IT82D889 and IT86D-1010). The maturity of the varieties under the various $\mathrm{P}$ applications and the cropping system were longer during the second season due to higher precipitation received during the crop growth period. Cowpea varieties tend to extend their flowering and pod production under favourable rainfall duration which leads to asynchrony of flowering and podding phases that directly prolong maturity period.

The significant interaction obtained between variety and $\mathrm{P}$ application for the root mass during both seasons suggests that root mass of the varieties was influenced by $\mathrm{P}$ application. Root mass increased with $\mathrm{P}$ application rates 
Asiwe et al. / Intl J Agric Biol, Vol 26, No 2, 2021

Table 4: Effect of phosphorus application and cropping system and its interactive effect on root mass, 100 seed mass and grain yield of plant height of cowpea varieties

\begin{tabular}{|c|c|c|c|c|c|c|}
\hline \multirow[t]{2}{*}{ Treatment } & \multicolumn{3}{|c|}{ Season 1} & \multicolumn{2}{|c|}{ Season 2} & \multirow[b]{2}{*}{ Grain yield $\left(\mathrm{kg} \mathrm{ha}^{-1}\right)$} \\
\hline & Root mass $\left(\mathrm{g} \mathrm{plant}^{-1}\right)$ & 100 seed mass $(\mathrm{g})$ & Grain yield $\left(\mathrm{kg} \mathrm{ha}^{-1}\right)$ & Root mass $\left(\mathrm{g} \mathrm{plant}^{-1}\right)$ & 100 seed mass $(\mathrm{g})$ & \\
\hline \multicolumn{7}{|c|}{ Phosphorus $\left(\mathrm{P} ; \mathrm{kg} \mathrm{ha}^{-1}\right)$} \\
\hline 0 & $21.96 \mathrm{a}$ & $15.43^{\mathrm{NS}}$ & $1275.00 \mathrm{a}$ & $17.60 \mathrm{a}$ & $16.93^{\mathrm{NS}}$ & $1598.15 \mathrm{a}$ \\
\hline 15 & $24.29 b$ & 15.51 & $1356.94 a$ & $17.44 \mathrm{a}$ & 16.57 & $1551.85 \mathrm{a}$ \\
\hline 30 & $24.93 b$ & 15.08 & $1350.00 \mathrm{a}$ & $18.28 \mathrm{a}$ & 16.92 & $1709.26 \mathrm{~b}$ \\
\hline 45 & $27.91 \mathrm{c}$ & 15.02 & $1643.06 \mathrm{~b}$ & $23.84 \mathrm{~b}$ & 16.96 & $1912.96 \mathrm{~b}$ \\
\hline \multicolumn{7}{|l|}{ Varieties (V) } \\
\hline IT82D-889 & $29.29 \mathrm{a}$ & $17.46 \mathrm{a}$ & $1208.26 \mathrm{a}$ & & & \\
\hline PAN311 & $22.47 \mathrm{~b}$ & $15.11 \mathrm{~b}$ & $2123.31 \mathrm{~b}$ & $21.40 \mathrm{a}$ & $17.62 \mathrm{a}$ & $1902.78 \mathrm{a}$ \\
\hline IT86D-1010 & $29.42 \mathrm{a}$ & $17.06 \mathrm{a}$ & $802.64 c$ & & & \\
\hline TVu13464 & $17.91 \mathrm{c}$ & $13.10 \mathrm{c}$ & $1293.06 \mathrm{a}$ & $15.20 \mathrm{~b}$ & $14.88 \mathrm{~b}$ & $1248.61 \mathrm{~b}$ \\
\hline \multicolumn{7}{|c|}{ Cropping system (CS) } \\
\hline Monocrop & $22.51 \mathrm{a}$ & $15.19 \mathrm{a}$ & 1399.31a & $18.56 \mathrm{a}$ & $16.72^{\mathrm{NS}}$ & $1570.37 \mathrm{a}$ \\
\hline $\begin{array}{l}\text { Intercrop } \\
\text { Interaction }\end{array}$ & $25.03 b$ & $15.40 \mathrm{a}$ & $1863.19 b$ & $20.72 b$ & 16.97 & $1938.43 b$ \\
\hline $\mathrm{V} \times \mathrm{P}$ & $<0.01$ & 0.38 & 0.04 & 0.05 & 0.34 & 0.31 \\
\hline $\mathrm{V} \times \mathrm{CS}$ & 0.45 & 0.11 & 0.03 & 0.01 & 0.25 & 0.05 \\
\hline $\mathrm{V} \times \mathrm{P} \times \mathrm{CS}$ & 0.25 & 0.47 & 0.09 & 0.15 & 0.17 & 0.63 \\
\hline
\end{tabular}

Table 5: Total land equivalent ratio for the component crops in the intercrop at different phosphorus rates $\left(0,15,30,45 \mathrm{~kg} \mathrm{P} \mathrm{ha}^{-1}\right)$

\begin{tabular}{|c|c|c|c|c|c|c|c|c|}
\hline \multirow[t]{2}{*}{ Variety } & \multicolumn{4}{|c|}{ Season 1} & \multicolumn{4}{|c|}{ Season 2} \\
\hline & 0 & 15 & 30 & 45 & 0 & 15 & 30 & 45 \\
\hline IT82D-889 + WE3127 & $1.98 \mathrm{a}$ & $2.09 \mathrm{~b}$ & $2.38 \mathrm{~d}$ & $2.51 \mathrm{~d}$ & - & - & - & - \\
\hline IT86D-1010+WE3127 & $2.15 \mathrm{c}$ & $1.99 \mathrm{a}$ & $2.17 \mathrm{c}$ & $2.66 \mathrm{e}$ & - & - & - & - \\
\hline TVu13464 + WE3127 & $2.17 \mathrm{c}$ & $2.05 \mathrm{~b}$ & $2.18 \mathrm{c}$ & $2.05 \mathrm{~b}$ & $1.00 \mathrm{a}$ & $1.10 \mathrm{a}$ & $1.20 \mathrm{c}$ & 1.20 \\
\hline
\end{tabular}

Table 6: Interactive effect of $\mathrm{P}$ application and intercropping systems on economic analysis of cowpea and maize yield

\begin{tabular}{|c|c|c|c|c|c|c|c|c|}
\hline $\begin{array}{l}\text { Phosphorus } \\
\left(\mathrm{kg} \mathrm{ha}^{-1}\right)\end{array}$ & $\begin{array}{l}\text { Maize relative } \\
\text { yield }\left(\mathrm{kg} \mathrm{ha}^{-1}\right)\end{array}$ & $\begin{array}{l}\text { Maize revenue } \\
\left(\mathrm{US} \$ \mathrm{ha}^{-1}\right)\end{array}$ & $\begin{array}{l}\text { Cowpea relative } \\
\text { yield }\left(\mathrm{kg} \mathrm{ha}^{-1}\right)\end{array}$ & $\begin{array}{l}\text { Cowpea revenue } \\
\left(\text { US } \$ h^{-1}\right)\end{array}$ & $\begin{array}{l}\text { Total revenue } \\
\left(\text { US } \$ \mathrm{ha}^{-1}\right)\end{array}$ & $\begin{array}{l}\text { Total cost } \\
\left(\text { US } \$ h^{-1}\right)\end{array}$ & $\begin{array}{l}\text { Total profit } \\
\left(\mathrm{US} \$ \mathrm{ha}^{-1}\right)\end{array}$ & $\mathrm{BCR}$ \\
\hline 0 & 2555.65 & 1459.33 & 1282.65 & 3662.10 & 5121.43 & 2052.63 & 3068.80 & 1.50 \\
\hline 15 & 2568.30 & 1466.55 & 1325.25 & 3783.73 & 5250.28 & 1998.17 & 3252.11 & 1.63 \\
\hline 30 & 3863.10 & 2205.91 & 1469.70 & 4196.15 & 6402.06 & 1992.86 & 4409.20 & 2.21 \\
\hline 45 & 5029.15 & 2871.75 & 1586.10 & 4528.48 & 7400.23 & 2367.34 & 5032.89 & 2.13 \\
\hline Intercropping & 3462.71 & 1977.28 & 1437.35 & 4103.78 & 6081.06 & 1871.15 & 4209.91 & 2.25 \\
\hline Monocropping & 3602.32 & 2057.00 & 1159.40 & 3310.20 & 5367.21 & 1697.46 & 3669.75 & 2.16 \\
\hline
\end{tabular}

$\mathrm{BCR}=$ Benefit-cost ratio; $1 \mathrm{USD}=14.01 \mathrm{ZAR}$

thus indicating that $\mathrm{P}$ is an important nutrient for root growth and development in plants. High root mass enhances plants' ability to absorb nutrients, water and increases stability to resist lodging (Namakka et al. 2017; Agoyi et al. 2017; Bawa 2020). Root mass was higher in the intercrop plots than the monocrop plots. However, root mass was lower during the second season which may suggest that rainfall must have negatively influenced the varieties to partition the applied $\mathrm{P}$ for the production of above ground plant parts such as the leaves, pods and flowers since the root mass was determined at plant maturity. That significant interaction was obtained between the cropping system and variety for plant height only during the second season is an indication of the sensitivity of the varieties to adequate moisture available as compared to when there is no enough moisture during the first season. This is the reason why the varieties could not discriminate their abilities under the various $\mathrm{P}$ application rates during the first season.
Phosphorus is not a mobile nutrient like N (Nziguheba et al. 2016) and therefore needs enough moisture for its sorption and uptake. Plant height was positively influenced by $\mathrm{P}$ application and cropping system during second season than the first thus indicating the impact soil moisture could play in enhancing P uptake in plants (Nkaa et al. 2014; Karikari et al. 2015; Yasser et al. 2018).

Similarly, the 100-seed weight and grain yield followed similar trend and were under the influence of rainfall abundance and distribution which were better during the second season. The significant interaction obtained between the variety and cropping system indicates that grain yield of varieties was influenced by the cropping system. Intercrop plots outperformed monocrop plots in terms of in grain yield thus suggesting that the intercropping environment enhanced the performance of the varieties (Asiwe and Maimela 2021). The differences obtained in the 100 -seed and grain yield between the two seasons were 
probably due to differences in the distribution and amount of rainfall received during the crop growth period as well as their genetic constitution. The study of Makoi (2019) found that varieties differed significantly on 100 -seed weight and this was attributed to their genetic differences. Furthermore, two varieties (PAN311 and TVu13464) performed better than IT82D-889 and IT86D-1010. PAN311 and TVu13464 offer promising cash returns to farmers not only due to their high grain yield but also their good adaptation to mature early in drought-prone region like Limpopo province. In other words, PAN311 and TVu13464 were able to utilise the available growth resources such as water, nutrient and light for grain yield production as well as their plant architecture being an erect cowpea type with open canopy which exposes most of their leaves to attract sunlight for better photosynthetic advantage and capacity than other varieties.

Intercropping achieved higher grain yield than monocropping due to several factors; crops under intercropping system tend to use natural resources more efficiently for growth and development, which might have partly resulted in an increased yield (Shah et al. 2019; Namatsheve et al. 2020; Maitra et al. 2020). Cowpea production in a diversified agro-ecosystem can be a reservoir for the naturally occurring biological control agents (Masvaya et al. 2017) that could reduce insect infestation, and thereby minimise yield loss due to insect pests (Sikora et al. 2020). In addition, soil moisture, soil temperature and microclimate are normally higher in an intercropping system compared to a monocropping system (Seran and Brintha 2010) and these factors when in abundance play a major role to enhance crop growth and development that can result in increased yield (Mndzebele et al. 2020). In addition, the faster ground cover often observed in the intercrop plots reduces weed growth, raindrop impact and soil water evaporation, thereby conserving soil moisture for effective crop growth and build-up of natural enemies (Muoni et al. 2020).

One of the findings from this study is that increasing $\mathrm{P}$ application rates $\left(30-45 \mathrm{~kg} \mathrm{P} \mathrm{ha}^{-1}\right)$ increased the LER values and financial returns. The calculated LER values for both growing seasons were greater than 1.0 (Nyasasi and Kisetu 2014; Asiwe and Maimela 2021). This implies a comparative advantage of intercropping maize with cowpea over growing each crop separately (Namatsheve et al. 2020), which suggests that there is a greater efficiency of land utilisation in the intercropping system (Kermah et al. 2017). This further shows that the same area of land under intercropping will produce nearly a double fold of grain yield or financial return than the same area of land under monocropping. The results from previous worker, Masvaya et al. (2017) reported that profit and LER values were higher for cowpea-maize intercrop and could vary from 1.8 to 2.5. The LER values achieved in this study ranged from 1.9 to 2.87 which are in conformity with previous results (El-Salam and El-Lateef 2015) who reported that intercropping was significantly better than in-row intercropping with respect to LER. Greater efficiency of land utilisation indicated by the LER $>1$ suggests resources were used more effectively under intercropping than monocropping systems (Khan et al. 2012; Masvaya et al. 2017). Although the profit increased with increasing $\mathrm{P}$ levels; however, since the BCR value declined at $45 \mathrm{P}$ $\mathrm{kg} \mathrm{ha}^{-1}$, it suggests that the associated marginal profit at this $\mathrm{P}$ level does not justify the extra cost of production thus indicating that the optimum level for profit maximization was achieved at $30 \mathrm{P} \mathrm{kg} \mathrm{ha}^{-1}$.

\section{Conclusion}

Phosphorus application influenced the performance of cowpea varieties, cropping system for better grain yield and the optimum $\mathrm{P}$ level for cowpea-maize strip intercropping was $30 \mathrm{~kg} \mathrm{P} \mathrm{ha}^{-1}$ during both seasons. Strip intercropping system was advantageous as compared to growing each crop separately; and showed greater efficiency of land utilisation in the intercropping system, and potential to increase household food security and income. Two promising cowpea varieties (PAN311 and TVu13464) performed well and were selected for intercropping system based on their early maturity and high yield.

\section{Acknowledgements}

The authors acknowledge the financial grant received from National Research Foundation for S\&F - Innovation Masters Scholarships (Grant Number: 94710) and the University of Missouri, USA/University of Western Cape, South Africa - Centre of Excellence (Project Number: 141101) to execute this study.

\section{Author Contributions}

All the authors contributed relevantly in the execution of the study and preparation of the manuscript and subsequent revisions

\section{Conflict of Interest}

There was no conflict of interest from my institution or from other organizations neither from the stations that research was conducted.

\section{Data Availability}

The data used in this publication are original and has not been used eslwhere and the right has been transferred to IJAB/FS to publish it with terms and conditions observed.

\section{Ethics Approval}

All ethical considerations were observed and there was no issues raised against the conduct of the study and publication of the data obtained from the study. 


\section{Funding Source}

The sources of funding of this study, National Reseach Foundation (NRF) of South Africa and the University of Missouri, USA/University of Western Cape, South Africa to execute this study have been duely acknowledged for their financial support.

\section{References}

Adeyemi OR, KO Ogunsola, PM Olorunmaiye, JO Azeez, DO Hosu, JA Adigun (2020). Effect of phosphorus (P) rates and weeding frequency on the growth and grain yield of extra early cowpea (Vigna unguiculata L. Walp.) in the forest-Savanna agro-ecological zone of southwest Nigeria. J Agric Sci 65:47-60

Agoyi EE, TL Odong, JB Tumuhairwe, G Chigeza, BW Diers, P Tukamuhabwa (2017). Genotype by environment effects on promiscuous nodulation in soybean (Glycine max L. Merrill). Agric Food Secur 6:29-42

Asiwe JAN (2009). Needs assessment of cowpea production practices, constraints and utilisation in South Africa. Afr J Biotechnol 8:5383-5388

Asiwe JNA, KA Maimela (2021). Yield and economic assessments of five cowpea varieties in cowpea-maize strip intercropping in Limpopo province, South Africa. Intl J Agric Biol 25:27-32

Asiwe JAN, IB Oluwatayo, DN Asiwe (2020). Enhancing food security, nutrition and production efficiency of high-yielding grain legumes in selected rural communities of Limpopo province. In: Production Guide, Training of Farmers and Cowpea Processing and Capacity Building, Vol. 2. WRC Report No. TT 829/2/20, Gezina, South Africa

Bawa A (2020). Yield response of cowpea to phosphorus fertilizer application. J Exp Agric Intl 42:125-135

Bremner JM (1955). Nitrogen distribution and amino-acid composition of fractions of a humic acid from a chernozem soil ("Hildesheimer Schwarzerde"). Zeits Pflanzener Dueng Bodenk 71:63-66

Chapman HD (1965). Cation exchange capacity. In: Methods of Soil Analysis. American Society of Agronomy, pp:891-901. Black CA (Ed). Madison WI

Dariush M, M Ahad, O Meysam (2006). Assessing the land equivalent ratio (LER) of two corn (Zea mays) varieties intercropping at various nitrogen levels in Karaj, Iran. J Centr Eur Agric 7:359-364

Eckert DJ (1988). Recommended $\mathrm{pH}$ and lime requirement tests. In: Recommended Chemical Soil Test Procedures for the North Central Region, p:68. Dahne WC (Ed). North Dakota, USA

El-Salam MA, HMA El-Lateef (2015). Effect of maize-cowpea intercropping on light interception, yield and land use efficiency. Intl J Chem Technol Res 8:556-564

Fulton A (2010). Understanding and Applying Information from a Soil Test, pp:1-22. Part $2-$ NPK

Gebregergis Z (2016). Cropping systems of East Africa: A review. Crop Res Core Proc 6:30-33

Karikari B, E Arkorful, S Addy (2015). Growth, nodulation and yield response of cowpea to phosphorus fertilizer application in Ghana. $J$ Agron 14:234-240

Kermah C, AC Franke, S Adjei-Nsiah, BDK Ahiabor, RC Abaidoo, KE Giller (2017). Maize-grain legume intercropping for enhanced resource use efficiency and crop productivity in the Guinea savanna of northern Ghana. Field Crops Res 213:38-50

Khan MB, M Khan, M Hussain, M Farooq, K Jabran, DJ Lee (2012). Bioeconomic assessment of different wheat-canola intercropping systems. Intl J Agric Biol 14:769-774

Kuo S (1996). Phosphorus. In: Methods of Soil Analysis. Chemical Methods. Soil Science Society of America Book, pp:869-919. Series No. 5. SSSA and ASA. Sparks DL (Ed). Madison, Wisconsin, USA

Kyei-Boahen S, CEN Savala, D Chikoye, R Abaidoo (2017). Growth and yield responses of cowpea to inoculation and phosphorus fertilization in different environments. Front Plant Sci 8; Article 646
Mafakheri K, MR Bihamta, AR Abbasi (2017). Assessment of genetic diversity in cowpea (Vigna unguiculata L.) germplasm using morphological and molecular characterisation. Cogent Food Agric 3; Article 1327092

Maitra S, T Shankar, P Banerjee (2020). Potential and advantages of maizelegume intercropping system, maize-production and use. Available at: https://www.intechopen.com/books/maize-production-anduse/potential-and advantages-of-maize-legume-intercropping-system (Accessed: 02 April 2021)

Makoi J (2019). Yield and yield components of local cowpea (Vigna unguiculata L.) landraces grown in mixed culture with maize (Zea mays L.) in vertic cambisols in the Northern part of Tanzania. For Res Eng Intl J 3:88-94

Masvaya EN, J Nyamangara, K Descheemaekerb, KE Gillerb (2017). Is maize-cowpea intercropping a viable option for smallholder farms in the risky environments of semi-arid southern Africa? Field Crops Res 209:73-87

Mndzebele B, B Ncube, M Fessehazion, T Mabhaudhi, S Amoo, C Plooy, S Venter, A Modi (2020). Effects of cowpea-amaranth intercropping and fertiliser application on soil phosphatase activities, available soil phosphorus, and crop growth response. Agronomy 10; Article 79

Mpandeli NS, E Nesamvuni, P Maponya (2015). Adapting to the impacts of drought by smallholder farmers in Sekhukhune district in Limpopo province, South Africa. J Agric Sci 7:115-124

Muoni T, E Koomson, I Öborn, C Marohn, CA Watson, G Bergkvist, A Barnes, G Cadisch, A Duncan (2020). Reducing soil erosion in smallholder farming systems in East Africa through the introduction of different crop types. Exp Agric 56:183-195

Namakka A, DM Jibrin, IL Hamma, J Bulus (2017). Effect of phosphorus levels on growth and yield of cowpea (Vigna unguiculata (L.) Walp.) in Zaria, Nigeria. J Dry Agric 3:85-93

Namatsheve T, R Cardinael, M Corbeels, R Chikowo (2020). Productivity and biological $\mathrm{N}_{2}$-fixation in cereal-cowpea intercropping systems in sub-Saharan Africa. A review. Agron Sustain Dev 40; Article 30

Nkaa FA, OW Nwokeocha, O Ihuoma (2014). Effect of phosphorus fertilizer on growth and yield of cowpea (Vigna unguiculata). $J$ Pharm Biol Sci 9:74-82

Nndwambi FH, IK Mariga, FR Kutu (2016). Growth and yield responses of pigeon pea to variable phosphorus application rates when intercropped with maize under dryland conditions. J Agric Crops 2:121-130

Nongqwenga N, AT Modi (2017). Phosphorus and potassium quantity/intensity properties of selected South African soils (Kwazulu Natal) and their correlation with selected soil parameters. Appl Ecol Environ Res 15:1-14

Nyasasi BT, E Kisetu (2014). Determination of land productivity under maize-cowpea intercropping system in agro-ecological zone of mount Uluguru in Morogoro, Tanzania. Glob Sci Res J 2:147-157

Nziguheba G, S Zingore, J Kihara, R Merckx, S Njoroge, A Otinga, B Vanlauwe (2016). Phosphorus in smallholder farming systems of sub-Saharan Africa: Implications for agricultural intensification. Nutr Cycl Agroecosyst 104:321-340

Odhiambo JJO, LE Nemadodzi (2007). Soil fertility management practices by smallholder farmers in Vhembe district, Limpopo province. $S$ Afr $J$ Agric Ext 36:53-61

Seran TC, I Brintha (2010). Review on maize based intercropping. J Agron 9:135-145

Shah MA, M Hussain, A Nawaz, K Jabran, S Farooq, M Farooq (2019). Relay intercropping improves growth and fiber quality of Bt. cotton. Intl J Agric Biol 22:1539-1546

Sikora RA, ER Terry, PL Vlek, J Chitja (2020). Transforming Agriculture in Southern Africa: Constraints, Technologies, Policies and Processes. Abingdon and Oxon, England

Sudharani Y, PP Mohapatra, K Pramanik, S Maitra (2020). Effect of different phosphorus levels on growth and yield of cowpea (Vigna unguiculata) genotypes. Intl J Manage Technol Eng 8; Article 11040802

Yasser E, E Ghobashy, AS Shams, MM Lamlom (2018). Maximizing land use efficiency by intercropping cowpea with some maize cultivars under different maize planting geometries. Agric Sci 9:1601-1620 